\title{
Host Plant Resistance in Different Black Gram Cultivars against Anthracnose
}

\author{
S.K. Aggarwal ${ }^{1}{ }^{*}$, B.L. Mali ${ }^{1}$, Amit Trivedi ${ }^{1}$, R.N. Bunker ${ }^{1}$, \\ L.S. Rajput ${ }^{2}$, Sudhir Kumar ${ }^{3}$ and Anurag Tripathi ${ }^{4}$
}

${ }^{1}$ Department of Plant Pathology, Rajasthan College of Agriculture Maharana Pratap

University of Agriculture and Technology, Udaipur-313001, Rajasthan, India

${ }^{2}$ Division of Plant Pathology, Indian Agricultural Research Institute, New Delhi, India

${ }^{3}$ Division of Plant Biotechnology, ICAR-IIPR, Kanpur-208024, Uttar Pradesh, India

${ }^{4}$ Department of Agriculture, Sharda University, Greater Noida-201306, Uttar Pradesh, India

*Corresponding author

\begin{tabular}{|c|c|}
\hline & A B S T R A C T \\
\hline Keywords & \multirow{4}{*}{$\begin{array}{l}\text { Black gram [Vigna mungo (L.) Hepper] is one of the most important grain legumes and } \\
\text { attacked by several foliar diseases that cause premature drying of leaves, resulting in } \\
\text { reduced black gram yields. An experiment was conducted to find out the stable source of } \\
\text { resistance against Anthracnose (Colletotrichum lindemuthianum). Total of six cultivars } \\
\text { (PU-30, PU-31, PU-38, PU-40, PUI-94-1 and TAU-1)of Black gram were evaluated under } \\
\text { in micro plots in Agronomy farm at Rajasthan college of agriculture, Udaipur during } 2013 \\
\text { and } 2014 \text { kharif season. The most virulent isolate (MVL) was utilized to screen the six } \\
\text { cultivars. Out of six cultivars, two cultivars PU-31 and PU- } 30 \text { were found to be moderately } \\
\text { resistant with per cent disease index (PDI) of } 28.40 \text { and } 31.40 \text { respectively. Two cultivars } \\
\text { PU- } 38 \text { and PU- } 40 \text { were found moderately susceptible with PDI of } 39.60 \text { and } 42.90 \\
\text { respectively. The remaining two cultivars TAU- } 1 \text { and PUI- } 94-1 \text { were susceptible with PDI } \\
\text { of } 47.20 \text { and } 51.40 \text { respectively. The study resulted in identification of two moderately } \\
\text { resistant cultivars (PU-30 and PU-31) can further be utilized in resistant breeding program. }\end{array}$} \\
\hline $\begin{array}{l}\text { Black gram, } \\
\text { Anthracnose, } \\
\text { Resistance, Percent } \\
\text { disease Index and } \\
\text { Moderately resistant }\end{array}$ & \\
\hline Article Info & \\
\hline $\begin{array}{l}\text { Accepted: } \\
\text { 07 February } 2019 \\
\text { Available Online: } \\
10 \text { March } 2019\end{array}$ & \\
\hline
\end{tabular}

\section{Introduction}

Blackgram [Vigna mungo (L.) Hepper] commonly known as urd bean, mash, black maple is an annual, semi erect to spreading herb belonging to the family fabaceae is grown as a kharif crop in tropical and subtropical countries. Urd bean has high nutritional value containing protein (24\%), fat (1.4\%), carbohydrate (59.6\%), calcium (154 $\mathrm{mg}$ ), phosphorus (385 mg), iron (9.1 mg), beta carotene $(38 \mathrm{mg})$, thiamine $(0.4 \mathrm{mg})$, riboflavin $(0.37 \mathrm{mg})$ and niacin $(2 \mathrm{mg})$ per 100 g seeds.

Sustainable black gram cultivation is continuously challenged by diseases that cause quantitative and qualitative losses in yield. The microorganisms that are present internally or externally cause considerable damage. The 
major diseases viz., Anthracnose (Colletotrichum lindemuthianum), Bacterial leaf blight (Xanthomonas phaseoli), Cerccospora leaf spot (Cercospora canescen) and Corynespora leaf spot (Corynespora casslicolli), Powdery mildew (Erysiphe polygoni), Root rot and Web blight (Rhizoctonia solani) and Stem canker (Macrophomina phaseolina) are reported in this crop. Among these Anthracnose, Web blight and Powdery mildew causes heavy losses to the crop.

Majid (1953) reported the Green gram anthracnose first time in India from Jorhat of Assam state in 1951.Anthracnose of Blackgram is caused by fungus $C$. lindemuthianum which attacks on all aerial plant parts and at all the stages of plant growth. Symptoms are circular, black, sunken spots with dark centre and bright red orange margins on leaves and pods. The yield losses caused by black gram anthracnose are proportional to the disease severity and vary remarkably depending on the stage of infection, genotypes and environmental conditions.

In India, anthracnose of black gram was earlier considered to be of minor importance but with intensification of black gram cultivation its severity has gradually increased. The pathogen particularly under cool and humid environmental conditions, resulting in 80 to $100 \%$ yield losses (Sharma et al., 2007).Limited work has been done to breed resistant varieties and fungicidal control is largely practiced.

However, host plant resistance is more ecofriendly and effective as it also will also reduce utilization chemicals as fungicides control is hazardous for soil as well as not economic for farmers. The present study was conducted to identify the resistance against anthracnose disease as resistant cultivars are the best and eco-friendly to manage a disease.

\section{Materials and Methods}

\section{Isolation}

Disease samples were collected from different places i.e. Mavli, Fatehnagar and RCA farm Udaipur, where urd bean is grown extensively. Diseased samples were carefully placed in polythene bags, properly tagged and brought to the laboratory. Isolations of the pathogen were attempted from infected urd bean leaves of all samples. The infected leaves were thoroughly washed in running tap water to remove the adhering soil. Diseased portions were cut into small pieces along with adjoining healthy area with the help of a sterilized scalpel, washed in sterilized water, surface sterilized by dipping in 0.1 per cent mercuric chloride solution 1:1000 $(\mathrm{HgCl} 2)$ for one minutes followed by rinsed thrice with sterilized distilled water and then transferred on two per cent potato dextrose agar (PDA) medium in Petri plate under aseptic conditions in laminar air flow. These were incubated at $28 \pm 2^{\circ} \mathrm{C}$ at least for 5 to 7 days for growth of the fungus. Fungal growth appeared in two to three days as white to grayish white. Sub cultures from uncontaminated periphery of the mycelial growth by hyphal tip culture method were made on PDA slants after 3-4 days.

\section{Identification of fungus}

Cultural characters of all isolates were studied by growing them on PDA medium. The identification of the fungus was done by comparing the morphological characters and reproductive structures of different isolates with binocular compound light microscope under laboratory conditions. The sporulating cultures were examined and identified on the basis of detailed morphological characters of somatic and reproductive characters up to species level with the help of standard description (Barnett and Hunter, 1972 and Holliday, 1980) as characterized from the initial cultures of the single conidium. 


\section{Multiplication of pathogen}

For artificial inoculation of anthracnose pathogen (C. lindemuthianum), most virulent isolate (MVL) multiplied separately on autoclaved sorghum grains. The sorghum grains were soaked overnight in water and washed with tap water. About 150 g grains were filled in polyethylene bags and autoclaved at a pressure of $1.045 \mathrm{~kg} \mathrm{~cm}^{-2}$ for one hour. The growth of the pure culture of each isolate was aseptically homogenized in $10 \mathrm{ml}$ sterile water with a sterilized needle. Whereas $5 \mathrm{ml}$ of homogenized culture was used for inoculating each polyethylene bag with their respective isolates. Inoculated bags were incubated at $28 \pm 2^{\circ} \mathrm{C}$ and after five days these bags were shaken manually every alternate day to obtain uniform distributed fungal growth on sorghum grains. After fifteen days, the profuse fungal growth and sporulation were washed with distilled water and filtered through muslin cloth, the spore suspension so obtained was used for inoculations of plants for creating disease in micro plots. The spore suspension strength $(1 \mathrm{x}$ $10^{3} \mathrm{spore} / \mathrm{ml}$ ) of most virulent isolate was sprayed on plants after 30 days of sowing.

\section{Spray Inoculation technique for host plant resistance}

On the basis of Pathogenicity and disease aggressiveness, The Mavli isolate of $C$. lindemuthianum was found to be most virulent and used in screening different six Blackgram cultivars viz., PU-30, PU-31, PU-38, PU-40, PUI-94-1 and TAU-1 were evaluated under inoculated conditions in micro plots. The pathogenic culture was inoculated on different cultivars to find out the resistant cultivars under field conditions.

\section{Inoculation of different cultivars}

For multiplication of most virulent isolate of C. lindemuthianum having strength of $1 \times 10^{3}$ spores per $\mathrm{ml}$ was prepared. This inoculum was sprayed on six different cultivars of black gram with five replications of each cultivar. After appearance of lesions on the leaves the PDI was gradually recorded up to maturity on the $0-5$ disease rating scale (Table 1). The observations for per cent disease index were recorded after 10 days of inoculation on a standard 0-5 disease rating scale for different 6 black gram cultivars.

\section{Results and Discussion}

Among the six cultivars (viz; PUI-94-1, TAU1, PU-40, PU-38, PU-30 and PU-31) PUI-94-1 exhibited (51.40 to 28.4) disease severity in decreasing order during 2013 respectively. Similarly in 2014, although the disease severity was slightly increased with (55.0 to 28.55) per cent in decreasing order respectively in each variety. In 2013the maximum mean PDI of 51.40and, which was more prone to anthracnose disease followed byTAU-1 with mean PDI of 47.2. The black gram variety PU-40 exhibited mean PDI(42.90 and PU-38 with mean PDI of 39.60 with moderate susceptibility reaction.

PU-30 and PU-31 cultivars found to be moderate resistant with mean PDI of 31.20 and 28.40 respectively. In 2014, PU-30 and PU-31 cultivars found moderate resistant with mean PDI of 29.33 and 28.55 respectively. The two variety viz; PU 40 and PU 38 exhibited moderate susceptibility against anthracnose of black gram. TAU-1 and PUI94-1 showed susceptibility against this disease with 49.33and 55.0 Percent disease severity (PDI) respectively.

The host Plant resistance study 6 black gram cultivars evaluated, among 6 cultivars PUI-941cultivar showed maximum PDI 51.40 which was found to be more prone to anthracnose and PU-31 showed minimum PDI 28.40 which was found least prone to anthracnose (Table 2). 
Table.1 Resistance scale on the basis of PDI mean value is listed below

\begin{tabular}{|l|l|l|}
\hline S.No. & PDI Range & Reaction \\
\hline 1. & $0 \%$ to $20 \%$ & Resistant \\
\hline $\mathbf{2 .}$ & $21 \%$ to $35 \%$ & Moderately Resistant \\
\hline 3. & $36 \%$ to $45 \%$ & Moderately Susceptible \\
\hline 4. & $46 \%$ to $70 \%$ & Susceptible \\
\hline 5. & More than $70 \%$ & Highly Susceptible \\
\hline
\end{tabular}

Table.2 Disease severity and reaction of most virulent isolate (MVL) of Colletotrichum lindemuthianum on different black gram cultivars

\begin{tabular}{|c|c|c|c|c|c|}
\hline S.No. & $\begin{array}{c}\text { Black gram } \\
\text { cultivars }\end{array}$ & $\begin{array}{c}\text { Disease severity/ } \\
\text { (PDI)* 2013 }\end{array}$ & $\begin{array}{c}\text { Disease severity/ } \\
\text { (PDI)* 2014 }\end{array}$ & Pooled mean & $\begin{array}{c}\text { Disease } \\
\text { Reaction }\end{array}$ \\
\hline $\mathbf{1 .}$ & PUI-94-1 & $51.40(45.8)$ & $55(47.87)$ & $53.20(46.83)$ & (S) \\
\hline $\mathbf{2 .}$ & TAU-1 & $47.20(43.3)$ & $49.33(44.62)$ & $48.26(43.96)$ & (S) \\
\hline $\mathbf{3 .}$ & PU-40 & $42.90(40.9)$ & $43.5(41.27)$ & $43.20(42.20)$ & (MS) \\
\hline $\mathbf{4 .}$ & PU-38 & $39.60(39.0)$ & $41.67(40.2)$ & 40.63 & (MS) \\
\hline $\mathbf{5 .}$ & PU-30 & $31.20(33.9)$ & $29.33(32.79)$ & 30.26 & (MR) \\
\hline $\mathbf{6 .}$ & PU-31 & $28.40(32.2)$ & $28.55(32.95)$ & $28.47(32.57)$ & (MR) \\
\hline & SEm \pm & 0.52 & 0.54 & 0.53 & \\
\hline CD (P= 0.05) & 1.62 & 1.72 & 1.67 & \\
\hline & $\mathbf{C V ( \% )}$ & 2.33 & 2.37 & 2.35 & \\
\hline
\end{tabular}

*Mean of three replications, Figures in parentheses are arcsine transformed values

We had evaluated six cultivars of Blackgram in the present However, Pathania et al., (2006) evaluated forty nine common bean lines comprising of exotic accessions and locally grown cultivars against Colletotrichum lindemuthianum exhibited differential resistance to its races in Himachal Pradesh, a north-western Himalayan state of India. Some exotic accessions like G 2333, Cornell 49242, PI 207262, Mexique 222, TO, Perry Marrow, Kaboon and Widusawere resistant to more than five Indian races, whereas two Indian accessions KRC-5 and Hans showed resistance to six and four races, respectively. Kiryakov (2009) studied virulence diversity of Colletotrichum lindemuthianum, the causal agent of the bean anthracnose; an expedition was undertaken to 6 locations in the Rhodope Mountain. Race 22 was the most frequent $(45.8 \%$ of the isolates). This race was virulent to the cultivars 'MDRK', 'Perry Marrow' and Widusa'. Races $6(26.5 \%)$ and $2(17.6 \%)$, came next in frequency. similarly, Rajesha et al., (2010) conducted field trials to elucidate the reaction of Dolichos bean genotypes to anthracnose (Colletotrichum lindemuthianum) under conditions of natural infection. Deshmukh et al., (2012) conducted a field experiment in rabi 2008 to screen five varieties and thirty-nine germplasms of Indian bean against anthracnose. Out of these, three varieties Kapasi, JNP-4, Katargam and two germplasms NWP8 and NWP21 showed 
resistant reaction against anthracnose while fifteen germplasms viz., NWP12, 19, 20, 22, $24,25,26,27,28,29,30,32,35,37,39$ were found to be moderately resistant, whereas variety NPS1 was found highly susceptible to anthracnose of Indian bean (Lablab purpureus $L)$ under south Gujarat conditions.

In conclusion, the study revealed that there was different type of disease reaction according to host genotype. The black gram cultivar PU-30 and PU-31 can be utilised further in resistant breeding programme.

\section{References}

Barnett, H.L., and Hunter, B.B. 1972. Illustrated genera of imperfect fungi Burgess Publication Lt. d, St. Paul, Minnesota, USA, Pp. 241.

Deshmukh, A.J., Mehta, B.P., Sabalpara, A.N., and Patil, V.A. 2012. Screening of Indian bean (Lablab purpureus L.) varieties/germplasms against anthracnose (Colletotrichum gloeosporioides Penz. and Sacc.) under field conditions. Journal of Biopesticides, 5:50-52.

Holliday, P., 1980. Fungal disease of tropical crops, Cambridge University Press, Cambridge, U.K., P.250.

Kiryakov, I., 2009. Virulence diversity of
Colletotrichum lindemuthianum in the Rhodope Mountain, Bulgaria Rasteniev'dni Nauki, 46:330-334.

Majid, S. (1953). Annals Report of department of agriculture, Assam for year ending $31^{\text {st }}$ March 1950. II, The Grow More Food Campaign, 11:107.

Pathania, A., Sharma, P.N., Sharma, O.P., Chahota, R.K., Ahmad, B. and Sharma, P. 2006. Evaluation of resistance sources and inheritance of resistance in kidney bean to Indian virulence of Colletotrichum lindemuthianum: evaluation of resistance in bean to anthracnose. Euphytica, 149:97-103.

Rajesha, G., Mantur, S.G., Ravishankar, M., Shadakshari, T.V. and Boranayaka, M. B. 2010. Screening of dolichos bean (Dolichos lablab L.) genotypes for resistance to anthracnose disease caused by Colletotrichum lindemuthianum. International Journal of Plant Protection, 3:135-136.

Sharma, P.N., Padder, B.A., Sharma, O.P., Pathania, A. and Sharma, P.(2007.Molecular Plant Pathology Laboratory, Department of Plant Pathology, CSK HP Agricultural University, Palampur, India. Australasian Plant Pathology, 36:191197.

\section{How to cite this article:}

Aggarwal, S.K., B.L. Mali, Amit Trivedi, R.N. Bunker, L.S. Rajput, Sudhir Kumar and Anurag Tripathi. 2019. Host Plant Resistance in Different Black Gram Cultivars against Anthracnose. Int.J.Curr.Microbiol.App.Sci. 8(03): 571-575. doi: https://doi.org/10.20546/ijcmas.2019.803.069 